\title{
KAWASAN WISATA AIR TERJUN DAIT DI KABUPATEN LANDAK
}

\author{
Windi Guswirno Hedi ${ }^{1}$, Syaiful Muazir ${ }^{2}$, Valentinus Pebriano ${ }^{3}$ \\ ${ }^{1}$ Mahasiswa, Jurusan Arsitektur, Fakultas Teknik, Universitas Tanjungpura. \\ windi.hedi@student.untan.ac.id \\ ${ }^{2}$ Jurusan Arsitektur, Fakultas Teknik, Universitas Tanjungpura \\ ${ }^{3}$ Jurusan Arsitektur, Fakultas Teknik, Universitas Tanjungpura
}

Naskah diajukan pada: 26 Agustus 2021

Naskah revisi akhir diterima pada: 31 Agustus 2021

\begin{abstract}
Abstrak
Kabupaten Landak memiliki banyak sumber daya alam yang berpotensi dijadikan objek wisata alam. Salah satunya Air Terjun Dait yang bertingkat 7 dan berada di kawasan hutan yang masih alami. Kawasan itu sering dikunjungi para wisatawan dari berbagai wilayah Kalimantan Barat. Namun terdapat beberapa permasalahan terkait sarana dan prasarana pendukung yang belum sesuai standar untuk kegiatan wisata, sehingga potensi kepariwisataanya belum maksimal. Untuk itu diperlukan perancangan "Kawasan Wisata Air Terjun Dait di Kabupaten Landak" yang sesuai standar kepariwisataan dan kebutuhan lingkungan setempat, dengan konsep ekowisata yang menggunakan pendekatan lingkungan berkelanjutan serta pemberdayaan masyarakat lokal. Penataan dilakukan dengan perancangan yang dimulai dari proses analisis fungsi, yang meliputi fungsi utama dan fungsi penunjang. Fungsi utama meliputi aspek-aspek rekreatif dan fungsi penunjang terdiri dari fungsi komersil, fungsi ekologis dan fungsi peran serta masyarakat. Metode perancangan terdiri dari tahapan pengenalan, definisi, persiapan, analisis, sintesis, evaluasi dan tahapan re-evaluasi. Proses perancangan tersebut diterapkan dalam pembangunan sarana dan prasarana utama kepariwisataan seperti area outbond, area camping, area swafoto, dan lainlain. Selain itu sarana dan prasarana penunjangnya seperti area pengelola, area komersil, area pelayanan, aspek utilitas, dan lain-lain. Dengan perancangan tersebut diharapkan Kawasan Wisata Air Terjun Dait akan lebih menarik para wisatawan dari berbagai wilayah yang lebih luas.
\end{abstract}

Kata-kata Kunci: Wisata, Air Terjun, Kabupaten Landak

\begin{abstract}
Landak Regency has many natural resources that have the potential to be used as natural tourism objects. One of them is Dait Waterfall which has 7 floors and is located in an unspoiled forest area. The area is often visited by tourists from various regions of West Kalimantan. However, there are several problems related to supporting facilities and infrastructure that are not up to standard for tourism activities, so that the tourism potential is not maximized. For this reason, it is necessary to design a "Dait Waterfall Tourism Area in Landak Regency" which is in accordance with tourism standards and local environmental needs, with the concept of ecotourism that uses a sustainable environmental approach and empowerment of local communities. The arrangement is done by designing which starts from the function analysis process, which includes the main functions and supporting functions. The main functions include recreational aspects and supporting functions consisting of commercial functions, ecological functions and community participation functions. The design method consists of the introduction, definition, preparation, analysis, synthesis, evaluation and re-evaluation stages. The design process is applied in the construction of the main tourism facilities and infrastructure such as outbound areas, camping areas, selfie areas, and others. In addition, supporting facilities and infrastructure such as management areas, commercial areas, service areas, utility aspects, and others. With this design, it is hoped that the Dait Waterfall Tourism Area will attract more tourists from a wider variety of areas.
\end{abstract}

Keywords: Tourism, Waterfall, Landak Regency 


\section{Pendahuluan}

Kabupaten Landak merupakan salah satu wilayah di Kalimantan Barat yang memiliki objek yang berpotensi menjadi kawasan wisata alam. Kekayaan alam yang selaras dengan lingkungan alam menjadi daya tarik utama untuk dikunjungi. Menurut data PERDA Kab. Landak No. 1 Tahun 2015, terdapat 29 objek wisata alam, yang 17 diantaranya merupakan wisata air terjun yang berada di Kecamatan Air Besar. Dari data prioritas pembangunan objek pariwisata di Kabupaten Landak berdasarkan urutan pembobotan alternatif yaitu, Riam Dait (27\%), Riam Banangar (19\%), Riam Solakng (19\%), Riam Setegung (18\%) dan Riam Angan (17\%). Data tersebut menjelaskan bahwa air terjun Dait menjadi prioritas utama pengembangan wisata alam yang dilakukan oleh Dinas Kepemudaan, Olahraga dan Pariwisata Kabupaten Landak, (DISPORAPAR Kabupaten Landak).

Air terjun Dait berada di Desa Sekendal, Kecamatan Air Besar, Kabupaten Landak, dan merupakan objek wisata alam yang pada umumnya didatangi oleh pengunjung lokal maupun asing (BPS Landak, 2017). Berdasarkan data pengunjung Wisata Air Terjun Dait, jumlah kunjungan wisatawan beragam menyesuaikan waktu tertentu. Jumlah kunjungan harian 5-10 orang, mingguan 10-20 orang dan hari libur lebih dari 100 orang.

Tingkat kunjungan wisatawan berdasarkan keindahan dan keunikan kawasan Air Terjun Dait sudah pada tahap pengembangan pemerintah dalam Peraturan Derah Kabupaten Landak No. 9 Tahun 2012 tentang Rencana Pembangunan Jangka Menengah Daerah (RPMJD) Kabupaten Landak tahun 2012-2016 dalam bentuk masterplan pariwisata. Partisipasi antara pihak pemerintah dan masyarakat desa setempat juga sudah terealisasi dalam mengelola Wisata Air Terjun Dait. Hal ini berdasarkan program Badan Usaha Milik Desa (BUMDes) yang bertugas mengatur keluar masuk dana desa dan secara mandiri masyarakat mengambil peran dalam pembangunan pariwisata daerah yang dikelola oleh Pokdarwis (Kelompok Sadar Wisata).

Pengembangan kawasan Wisata Air Terjun Dait sudah dilakukan oleh pemerintah dan masyarakat setempat yang diatur dalam PERDA Kabupaten Landak No. 2 Tahun 2010 dan sesuai dengan visi dan misi pariwisata pemerintah Kabupaten Landak. Namun pengelolaan yang dilakukan belum maksimal dan tidak adanya rancangan desain yang bisa mengakomodir seluruh kegiatan pariwisata disana. Sehingga menyebabkan beberapa permasalahan yaitu fasilitas yang disediakan belum memenuhi standar dan lingkungan alami sekitar objek air terjun terganggu serta pelayanan kepada wisatawan belum terpenuhi. Fasilitas-fasilitas tersebut meliputi, fasilitas pelayanan, fasilitas akomodasi, fasilitas keamanan dan area komersil. Masalah lainnya belum tersedianya jalur khusus untuk mengeksplorasi lokasi-lokasi di sekitar air terjun sehingga mengurangi pengalaman wisatawan dalam berekreasi. Untuk menyelesaikan masalah tersebut maka dibutuhkan rancangan desain "Kawasan Wisata Air Terjun Dait di Kabupaten Landak" dengan pendekatan lingkungan berkelanjutan serta menyediakan kebutuhan wisatawan sesuai dengan fungsi-fungsi pada kawasan wisata.

Perancangan Kawasan Wisata Air Terjun Dait menggunakan konsep ekowisata karena prinsipprinsipnya sesuai dan efektif untuk menyelesaikan masalah pada lokasi perancangan. Prinsip ekowisata yang diterapkan yaitu natural area focus, environmental sustainability practice, benefit local communities, cultural respect, dan customer expectation, (Arachchi, 2015). Diharapkan perancangan yang dilakukan dapat menyelesaikan permasalahan kawasan wisata terkait konteks lingkungan, kebudayaan masyarakat dan kondisi lingkungan alamiah.

\section{Kajian Pustaka}

Pariwisata menurut UU No. 10 Tahun 2009 adalah macam kegiatan wisata yang didukung oleh berbagai fasilitas serta layanan yang disediakan masyarakat, pengusaha, dan pemerintah. Pariwisata didefinisikan sebagai proses kegiatan datang dan keluar yang timbul dari hubungan dan interaksi di kalangan wisatawan, pemasok pariwisata, pemerintah setempat, masyarakat setempat, dan lingkungan sekitarnya yang terlibat sebagai daya tarik wisatawan. Kepariwisataan terkait pengunjung adalah 
industri seluruh perjalanan, hotel, transportasi, dan semua komponen lain yang termasuk promosi dan pelayanan kebutuhan pengunjung (Goeldner \& Ritchie, 2009).

Berdasarkan UU No. 9 Tahun 1990 pengertian kawasan wisata adalah suatu kawasan yang mempunyai luasan tertentu yang dibangun dan disediakan untuk kegiatan pariwisata. Menurut SK MENPARPOSTEL No.: KM. 98/PW. 102/MPPT-87, objek wisata adalah semua tempat atau keadaan alam yang memiliki sumber daya wisata yang dibangun dan dikembangkan sehingga mempunyai daya tarik dan diusahakan sebagai tempat kunjungan wisatawan. Panduan mengenai standar dan persyaratan pembangunan fasilitas kawasan wisata berdasarkan Peraturan Menteri Pariwisata Republik Indonesia Nomor 3 Tahun 2018 tentang Petunjuk Operasional Pengelolaan Dana Alokasi Khusus Fisik Bidang Pariwisata. Beragam fasilitas meliputi bangunan pusat informasi pariwisata (TIC), ruang ganti/ toilet, taman, pagar pembatas, kios cinderamata (souvenir), plaza pusat jajanan/ kuliner, tempat ibadah, menara pandang, gapura identitas, boardwalk, jalur pejalan kaki, tempat parkir, rambu penunjuk arah. Dimensi yang disarankan untuk bangunan informasi pelayanan memiliki minimal ukuran $9 \times 7$ meter, ruang ganti 1,6 x 1,8 meter, gazebo $2 \times 3$ meter, tinggi pagar pembatas 1,2 meter, tinggi menara pandang 3 meter dengan luas $20 \mathrm{~m}^{2}$, jalur boardwalk lebar 2 meter dengan tinggi pagar pengaman 0,9 meter.

Jenis wisatawan yang berkunjung cukup beragam yang dikategorikan dalam 3 kelompok yaitu allocentris, psycocentris dan mid-centris dalam Sunaryo (2013). Kelompok allocentris merupakan wisatawan yang berkunjung ke tempat yang dianggap baru. Kunjungannya berupa petualangan dan menggunakan saran di kawasan wisata tersebut. Kelompok psycocentris merupakan wisatawan yang hanya ingin berkunjung ke daerah wisata dengan kriteria fasilitas yang sesuai tempat tinggalnya. Sedangkan kelompok mid-centris merupakan wisatawan yang memiliki tipologi antara allocentris dan psycocentris.

\section{Metode}

Metode yang digunakan dalam perancangan Kawasan Wisata Air Terjun Dait di Kabupaten Landak ialah metode perancangan R. Whitaker, (Snyder \& Catanese, 1989). Proses yang dilakukan melalui tahapan pengenalan, definisi, persiapan, analisis, sintesis, evaluasi dan tahapan re-evaluasi. Ketujuh tahapan tersebut saling terkait dengan menyesuaikan karakteristik kawasan wisata.

Tahapan pengenalan diawali dengan isu-isu mengenai potensi dan permasalahan kawasan wisata. Latar belakang masalah yang merupakan tahap definisi yang merujuk pada informasi tentang kunjungan wisatawan, studi literatur, wawancara langsung dan informasi lainnya terkait objek Wisata Air Terjun Dait. Tahap persiapan yaitu pengumpulan data primer berupa eksplorasi eksisting maupun dengar pendapat pengurus kegiatan wisata, pengunjung dan masyarakat sekitar. Tahap analisis merupakan proses mencari solusi permasalahan yang meliputi analisis fungsi, analisis pelaku, analisis ruang, analisis lokasi, analisis tapak, analisis bentuk, analisis struktur, analisis utilitas, dan analisis fisika bangunan. Tahap sintesis berupa konsep yang menghasilkan skematik ruang luar dan dalam, serta bentuk-bentuk tiga dimensi bangunan dan lingkungannya untuk penerapan analisis bentuk, struktur, utilitas dan fisika bangunan. Tahap evaluasi berupa konsep perencanaan dan perancangan. Tahap re-evaluasi berupa pemeriksaan hasil akhir yang meliputi gambar prarancangan, gambar rencana arsitektural, gambar rencana struktural, dan gambar rencana utilitas.

\section{Hasil dan Pembahasan Lokasi Perancangan}

Lokasi perancangan di Desa Sekendal, Kecamatan Air Besar Kabupaten Landak, Provinsi Kalimantan Barat, Indonesia. Luas kawasan yang akan dibangun yaitu $32.120 \mathrm{~m}^{2}$ dengan prioritas area air terjun tingkat 1 dan tingkat 2. Luas area yang dapat dikelola menjadi tempat wisata paling maksimal $10 \%$ luas blok pemanfaatan hutan lindung (Peraturan Menteri Kehutanan Republik Indonesia No. P.22 Menhut-II/ 2012). Lokasi perancangan dilihat pada gambar 1. 


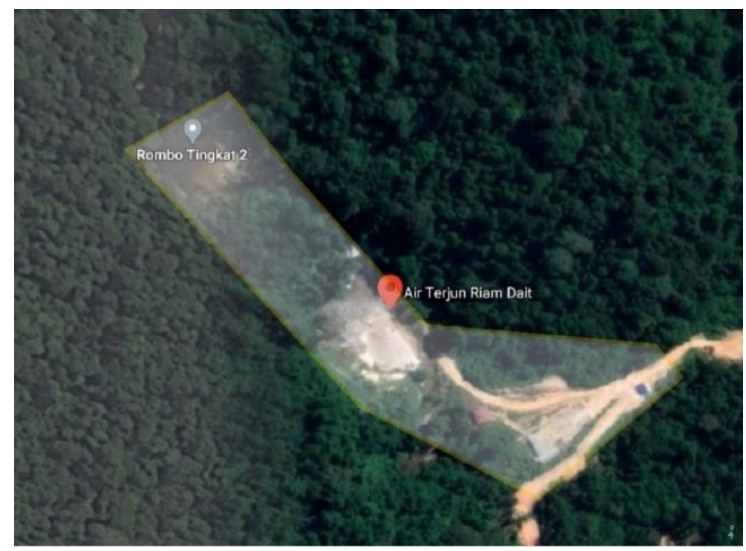

Gambar 1. Lokasi Perancangan Kawasan Wisata Air Terjun Dait di Kabupaten Landak Sumber: Penulis, 2021

\section{Fungsi}

Fungsi pada perancangan kawasan Wisata Air Terjun Dait di Kabupaten Landak mengacu pada tinjauan aktivitas dan kegiatan wisata air terjun yang tergolong wisata alam. Kegiatan wisata secara teoritik berkenaan dengan komponen daya tarik dan syarat destinasi wisata alam. Komponen daya tarik wisata ditentukan berdasarkan daya tarik wisata alam, atraksi wisata, amenitas, aksesibilitas, fasilitas pendukung, serta kelembagaan pariwisata. Komponen daya tarik wisata tersebut berhubungan dengan syarat destinasi wisata yang memiliki variable; 'something to see', 'something to do' dan 'something to buy'. Implementasi kegiatan Wisata Air Terjun Dait secara teoritik mengacu pada ketiga variabel tersebut. Sedangkan implementasi fungsional mengacu pada komponen daya tarik wisata tersebut.

Dari analisis tersebut fungsi-fungsi diklasifikasikan dalam sebuah skema, (lihat gambar 2).

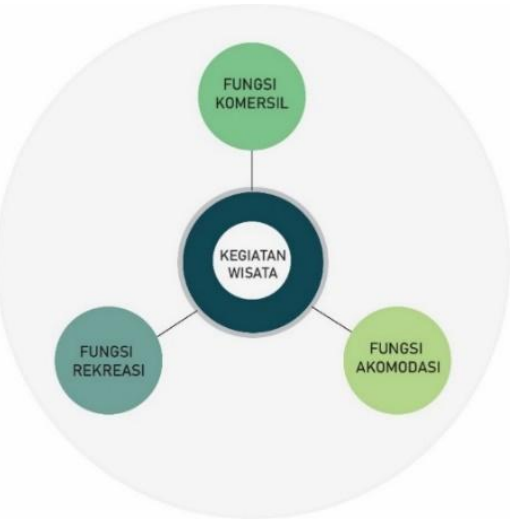

Gambar 2. Skema Fungsi Kawasan Wisata Air Terjun Dait di Kabupaten Landak Sumber: Penulis, 2021

\section{Tema Perancangan}

Tema perancangan kawasan wisata berdasarkan rumusan ide yang disusun untuk menyelesaikan permasalahan utama. Konsep tema mengacu pada permasalahan utama kawasan wisata yaitu belum adanya fasilitas standar aktifitas kepariwisataan. Penataan fasilitas kawasan wisata memperhatikan lingkungan alam sekitar berupa area hutan lindung. Berdasarkan hal tersebut, konsep perancangannya mengacu pada ekowisata serta pemberdayaan masyarakat sekitar. Penerapan perancangan mengacu pada prinsip-prinsip ekowisata yang diimplementasikan dalam desain arsitektural. 


\section{Konsep Program Ruang}

Konsep program ruang dalam perancangan kawasan diklasifikasikan 2 golongan ruang berdasarkan prporsi penggunaannya, berupa ruang berskala makro dan mikro. Konsep program ruang makro merupakan ruang-ruang meliputi ruang kantor pengurus, kafetaria, kios penjualan, dan ruang akomodasi penginapan. Program ruangberskala mikro merupakan konsep yang menghasilkan bagianbagian ruang dari aktivitas pelaku wisata berupa ruang publik seperti ruang pelayanan, area rekreasi terbangun dan rekreasi alam.

Program ruang pada perancangan kawasan Wisata Air terjun Dait dijabarkan pada tabel 1.

Tabel 1. Program Ruang Kawasan Wisata Air Terjun Dait di Kabupaten Landak

\begin{tabular}{|c|c|c|c|}
\hline Pelaku & $\begin{array}{c}\text { Aktivitas Pelaku } \\
\text { Kegiatan }\end{array}$ & Kebutuhan Ruang & Sifat Ruang \\
\hline \multirow{15}{*}{$\begin{array}{l}\text { Pengunjung/ } \\
\text { wisatawan }\end{array}$} & Parkir & Lahan parkir & Publik \\
\hline & Menanyakan informasi & Ruang informasi/lobby & Publik \\
\hline & Menunggu & Ruang tunggu & Publik \\
\hline & Piknik & Gazebo & Publik \\
\hline & Membeli cinderamata & Kios cinderamata & Publik \\
\hline & Berkeliling & Boardwalk & Publik \\
\hline & Berfoto & Foto area & Publik \\
\hline & Membaca & Perpustakaan & Publik \\
\hline & Camping & Camping area & Publik \\
\hline & Kegiatan outbond & Area outbond & Publik \\
\hline & Menginap & Bungalow & Publik \\
\hline & Ganti pakaian & Ruang ganti & Servis \\
\hline & Istrirahat & Kafetaria & Publik \\
\hline & Ibadah & Mushola & Servis \\
\hline & Kegiatan MCK & Toilet & Servis \\
\hline \multirow{15}{*}{ Pengelola } & Parkir & Lahan parkir & Publik \\
\hline & Orientasi & Lobby & Publik \\
\hline & Absen & Ruang absen & Semi privat \\
\hline & Ganti seragam & Ruang ganti & Servis \\
\hline & Bekerja (pengurus) & Ruang kerja & Privat \\
\hline & Menerima tamu & Ruang tamu & Semi Publik \\
\hline & Rapat koordinasi & Ruang rapat & Privat \\
\hline & $\begin{array}{l}\text { Menyusun administrasi } \\
\text { kegiatan }\end{array}$ & Ruang administrasi & Privat \\
\hline & Menjual tiket & Loket tiket & Publik \\
\hline & Bekerja (petugas teknis) & Ruang MEE & Publik \\
\hline & $\begin{array}{l}\text { Mengontrol plumbing dan } \\
\text { kelistrikan }\end{array}$ & Ruang kontrol & Servis \\
\hline & Mengontrol keamanan & Menara pandang & Servis \\
\hline & Ibadah & Mushola & Servis \\
\hline & Istirahat & Ruang istirahat, kafetaria, pantri & Publik \\
\hline & Kegiatan MCK & Toilet & Servis \\
\hline
\end{tabular}

Sumber: Penulis, 2021 


\section{Konsep Tapak}

Konsep tapak ditinjau berdasarkan zoning, perletakan, orientasi, sirkulasi, dan vegetasi. Konsep zoning merupakan proses analisis tapak yang diawali dengan analisis iklim terkait sinar matahari dan iklim, serta sirkulasi yang potensi dan masalahnya dianalisis untuk menentukan titik zonasi potensial seperti zona publik, privat, serta servis. Zona privat dan semi privat berada di sisi timur dan zona servis berada di sisi barat dengan paparan sinar matahari yang lebih banyak. Titik zonasi pada tapak dilihat pada gambar 3 .

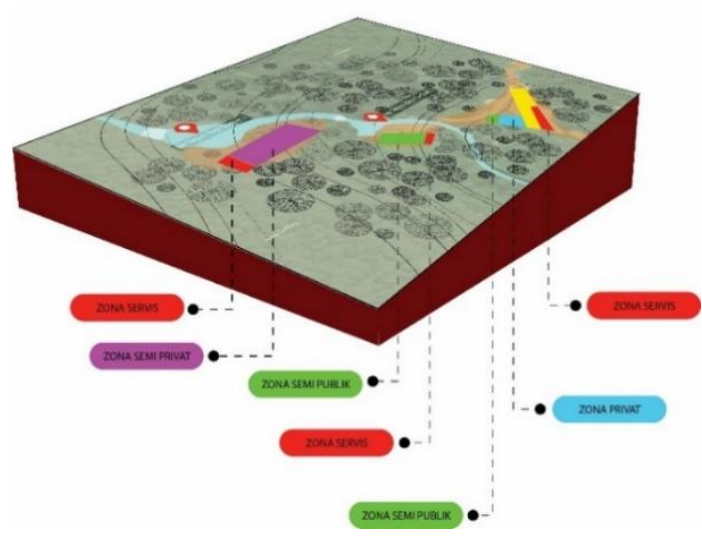

Gambar 3. Konsep Zoning

Sumber: Penulis, 2021

Konsep orientasi berupa simpulan dari analisis terhadap potensial objek wisata pada kawasan. Orientasi utama mengarah pada air terjun yang berada di timur kawasan. Orientasi gazebo ke utara kawasan yang terdapat air terjun. Orientasi potensial dalam perancangan dapat dilihat pada gambar 4 .

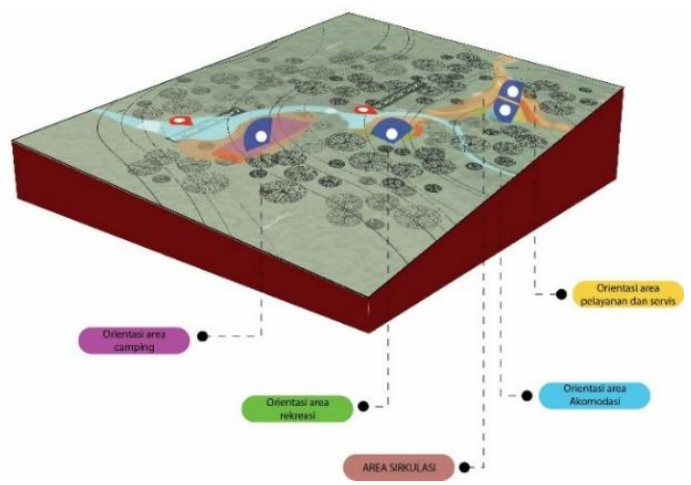

Gambar 4. Konsep Orientasi

Sumber: Penulis, 2021

Konsep sirkulasi terdiri dari arah masuk dan keluar, dan sirkulasi antar bagian di dalam kawasan wisata. Akses keluar-masuk kawasan berada di jalur utama ditandai dengan gerbang sebagai penanda utama kawasan. Sirkulasi di dalam kawasan berupa jalur alami dan jalur khusus (misalnya boardwalk, jembatan, jalan setapak) untuk mempermudah wisatawan untuk mengakses setiap bagian kawasan. Setiap jalur sirkulasi terhubung sebagai satu kesatuan aksesibilitas. Ilustrasi jalur sirkulasi dapat dilihat pada gambar 5. 


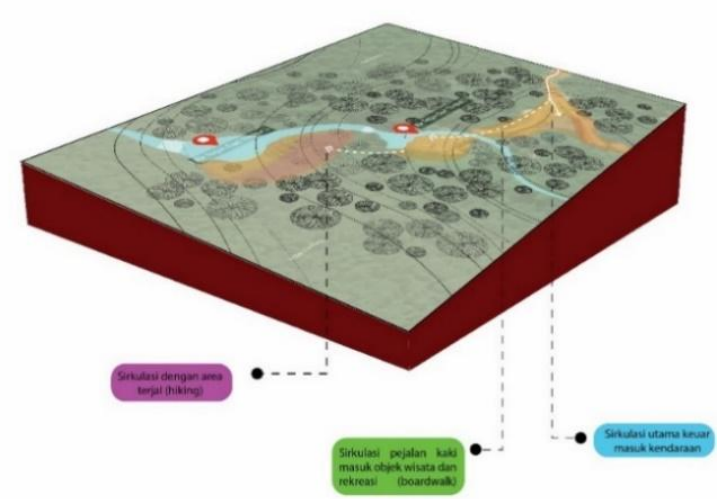

Gambar 5. Konsep Sirkulasi

Sumber : Penulis, 2021

Konsep perletakan merupakan hasil analisisa arsitektural yang didukung peraturan daerah terkait tata bangunan. Konsep arsitektural menyesuaikan kondisi geografis dan rona lingkungan. Kedua aspek tersebut tata letak dan orientasi bangunan. Konsep perletakan dapat dilihat pada gambar 6 .

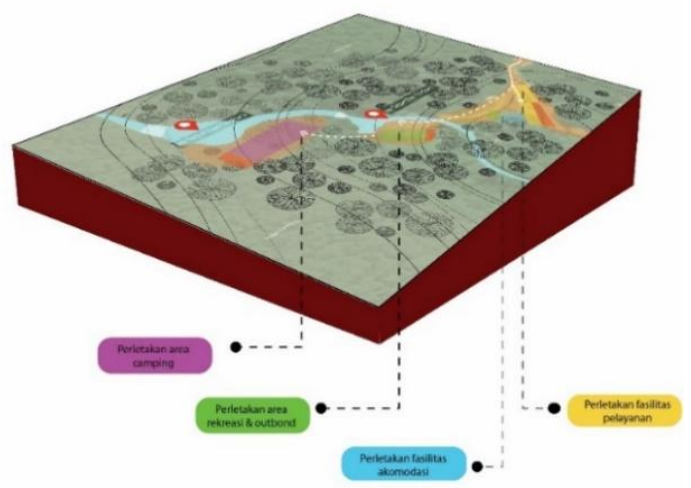

Gambar 6. Konsep Perletakan

Sumber: Penulis, 2021

Konsep vegetasi berupa pemanfaatan tanaman eksisting dan jenis tanaman lain yang didatangkan dari luar. Kelompok vegetasi yang didatangkan dari luar berupa vegetasi peneduh, pengarah dan estetika. Vegetasi peneduh misalnya pohon mahoni, pohon trembesi dan pohon pucuk merah. Vegetasi pengarah misalnya pohon glodokan tiang, pohon cemara dan pohon palm. Sedangkan vegetasi estetika yakni bunga bougenvil, bunga puring, bunga kembang sepatu, dan lain-lain.

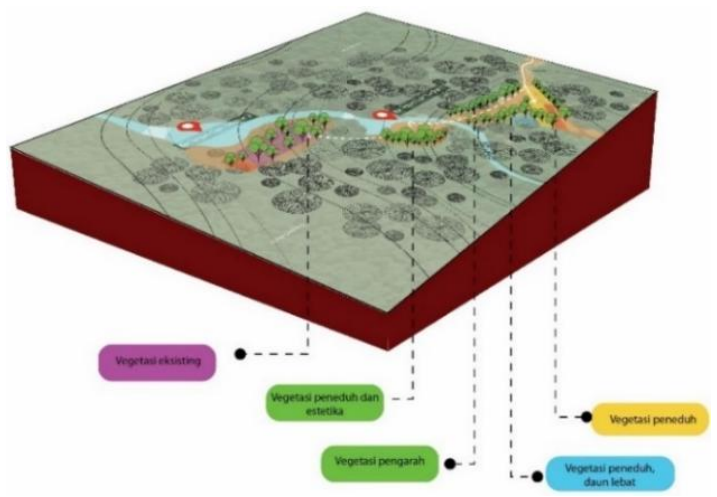

Gambar 7. Konsep Vegetasi

Sumber: Penulis, 2021 


\section{Konsep Bentuk}

Konsep bentuk menyesuaikan karakteristik kontur kawasan dan gubahan masa bangunan. Tahapan analisis bentuk terdiri dari lima yaitu bentukan awal yang mengikuti konsep zoning, adaptasi fungsi, filosofi dan pengurangan-penambahan bentuk, orientasi bentuk, bentukan akhir. Proses gubahan dilihat pada gambar 8 .

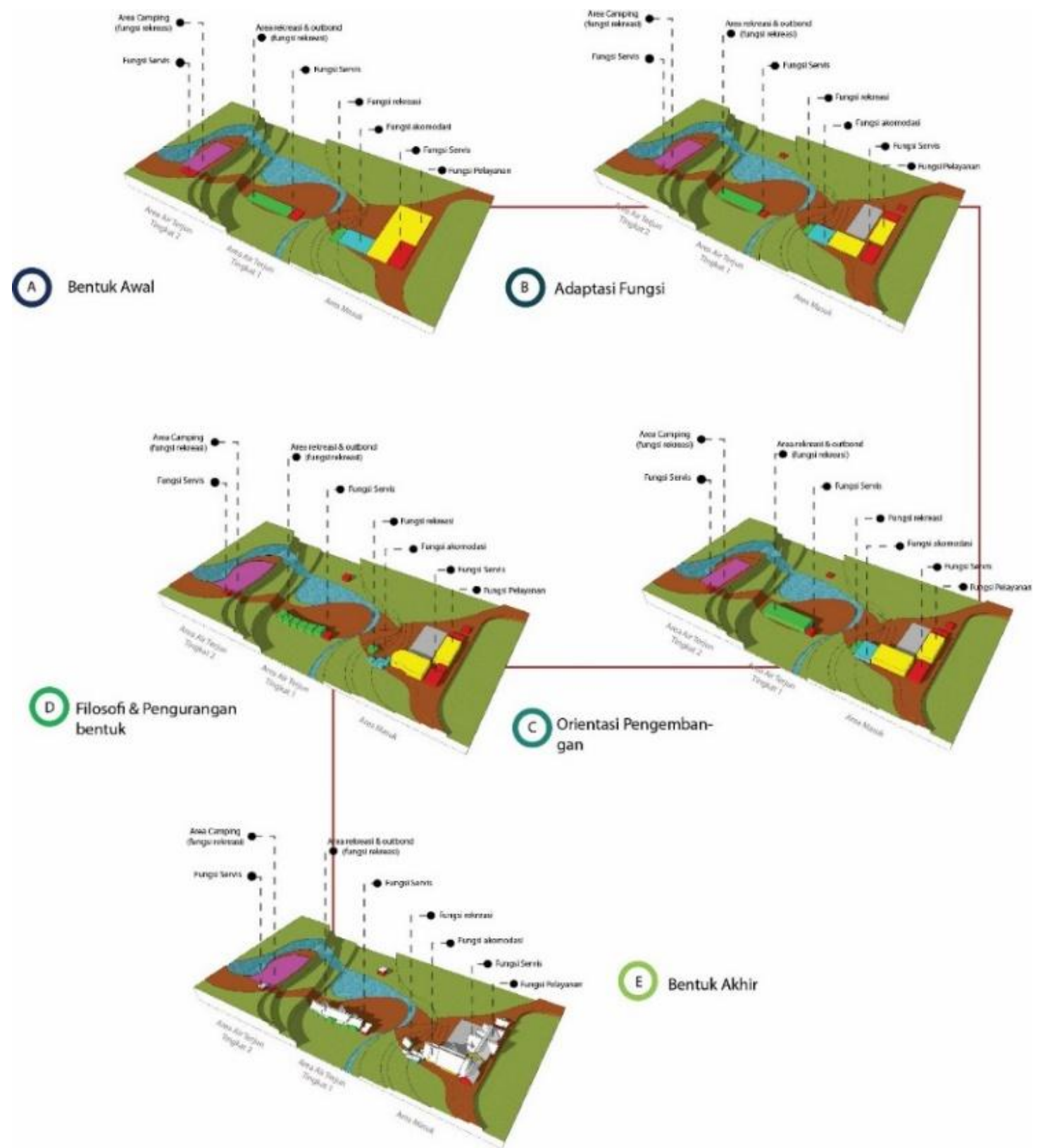

Gambar 8. Konsep Bentuk

Sumber: Penulis, 2021

\section{Konsep Struktur}

Konsep struktur bangunan meliputi struktur atas dan bawah yang ditentukan berdasarkan hasil analisis elemen struktur. Bagian penopang bangunan khususnya sistem pondasi menyesuaikan elevasi dan kontur lansekap. Struktur atas bangunan berupa bangunan bentang tidak lebar. Material penutup atap berupa rumbia yang memiliki beban ringan serta ramah lingkungan. Bentuk konsep struktur dapat dilihat pada gambar 9 . 

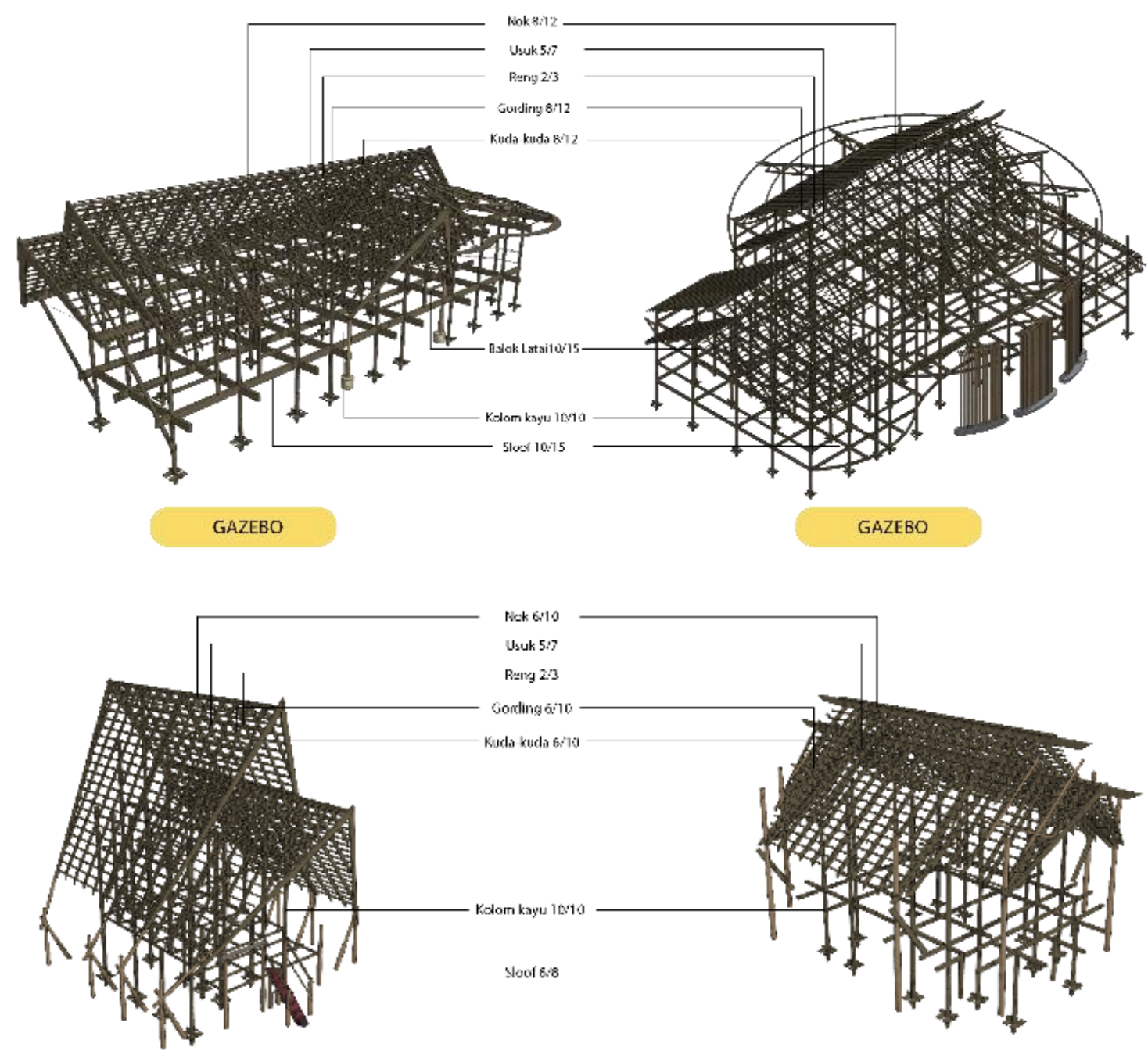

GAZEBO

Gambar 9. Aksonometri Konsep Struktur Sumber: Penulis, 2020

\section{Konsep Utilitas}

Konsep utilitas bangunan dan lingkungan meliputi sistem air seperti air bersih, air kotor, air bekas, air hujan, sistem kelistrikan, sistem pemadam kebakaran, sistem penangkal petir dan sistem persampahan. Sistem up-feed dan down-feed diterapkan pada pengelolaan air bersih. Sedangkan sumber listrik bersumber dari solar panel dan generator. Sistem pemadam kebakaran akan diterapkan berdasarkan standar-standar yang belaku seperti penyediaan hydrant box dibeberapa titik, hydrant lapangan dan titik evakuasi. Jaringan persampahan diletakan di beberapa titik pada kawasan. 


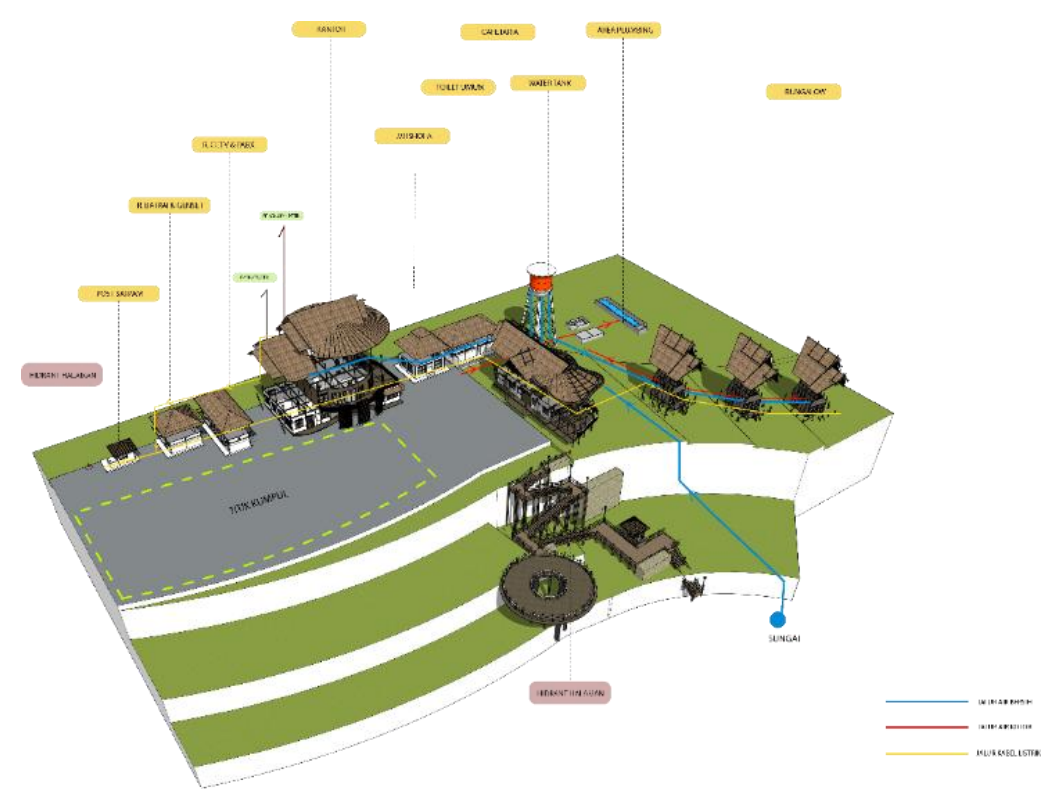

Gambar 10. Aksonometri Konsep Utilitas

Sumber: Penulis, 2021

\section{Konsep Fisika Bangunan}

Konsep fisika bangunan memanfaatkan bukaan bangunan serta penyesuaian material yang dapat mereduksi panas sinar matahari. Bukaan bangunan berfungsi memaksimalkan cahaya alami dan sirkulasi udara dari dan ke dalam bangunan. Ilustrasi dapat dilihat pada gambar 11 .

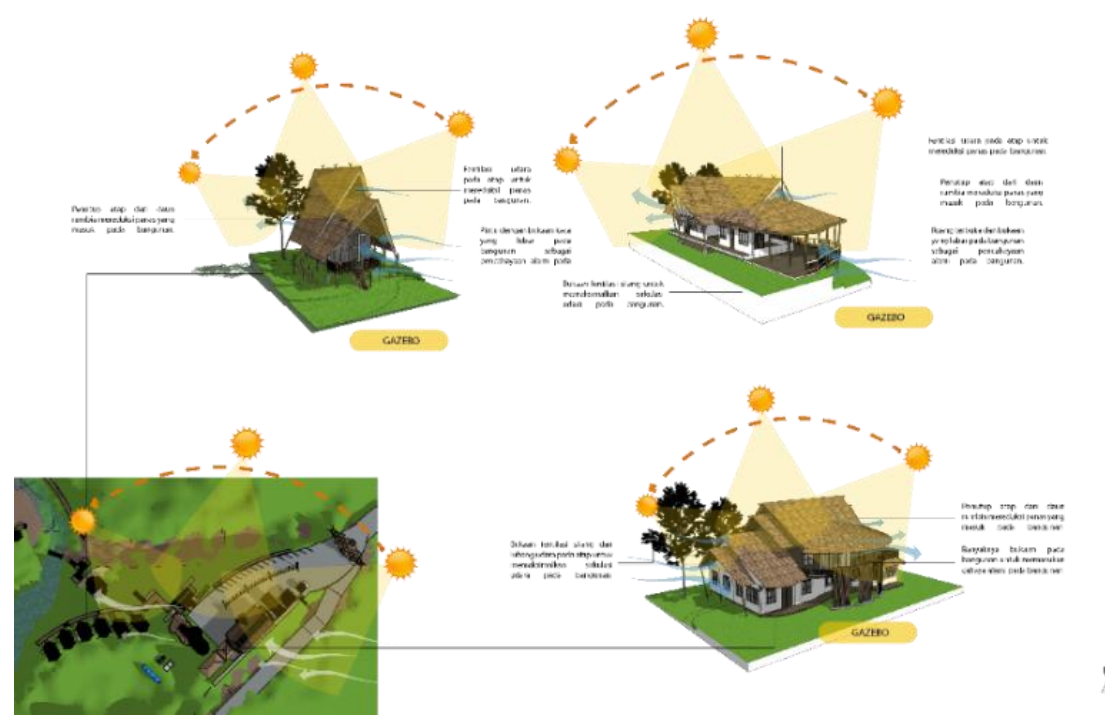

Gambar 11. Konsep Fisika Bangunan

Sumber: Penulis, 2021

\section{Siteplan}

Siteplan ditentukan berdasarkan analisis tapak dan sirkulasi serta analisis lainnya. Sirkulasi utama meliputi akses keluar-masuk yang terhubung dengan akses ke berbagai fasilitas pendukung kepariwisataan. Siteplan mengorganisir seluruh aktifitas rekreatif, kepengelolaan beserta komponen pendukungnya. 


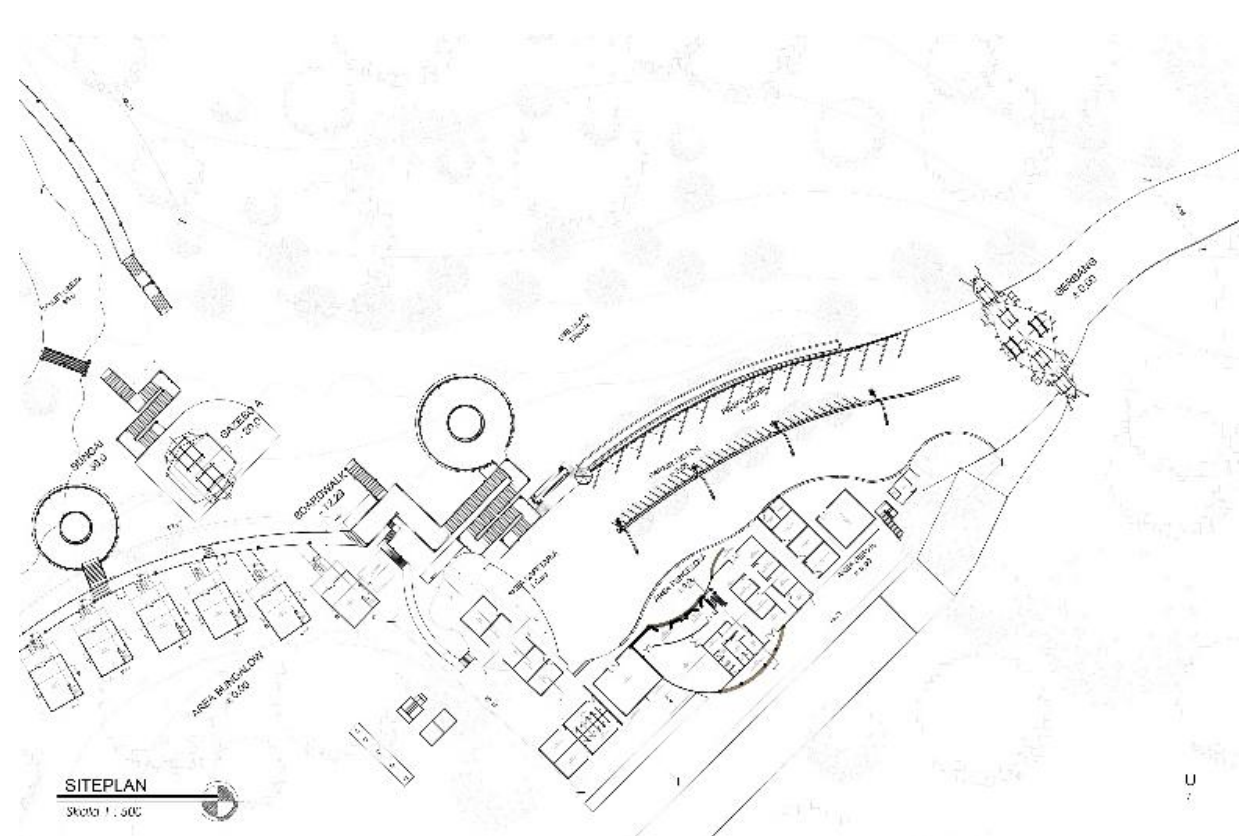

Gambar 12. Siteplan

Sumber: Penulis, 2021

\section{Denah}

Rancangan denah menyesuaikan fungsi-fungsi kepariwisataan (rekreatif), kepengelolaan (pelayanan), dan komponen pendukungnya serta karakteristik kontur dan rona lingkungan. Pada bangunan yang terpisah dihubungkan bentuk-bentuk akses terbuka berupa jembatan, boardwalk, dan koridor.

Denah kantor pengelola berupa memuat area penerima pengunjung dan area kerja. Area kerja berupa ruang kepala, ruang seksi, ruang rapat, ruang arsip, dan sebagainya. Letak bangunan berdekatan dengan area kafetaria,penjualan souvenir, bungalow, dan area fungsi lainnya yang terhubung melalui akses terbuka tersebut.

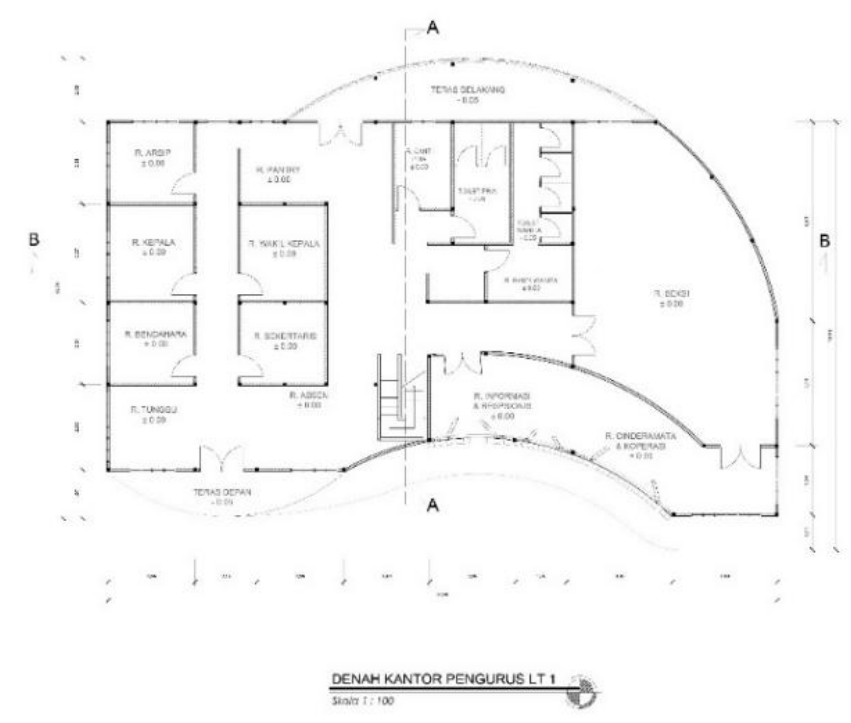

Gambar 13. Denah Kantor Pengurus Lantai Dasar Sumber: Penulis, 2021 


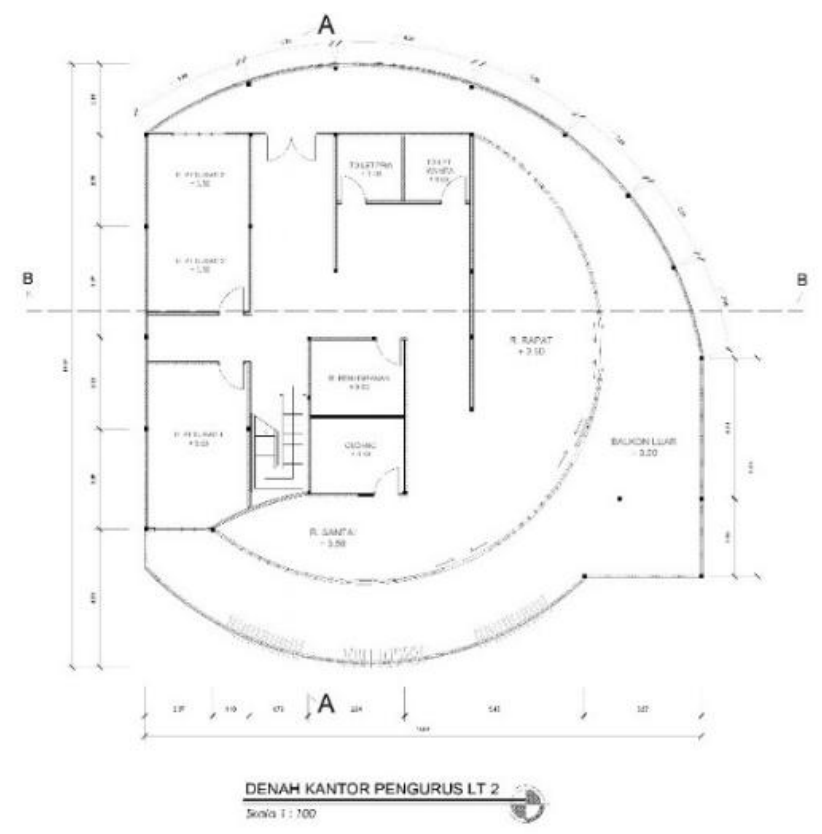

Gambar 14. Denah Kantor Pengurus Lantai 1 Sumber: Penulis, 2021

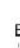

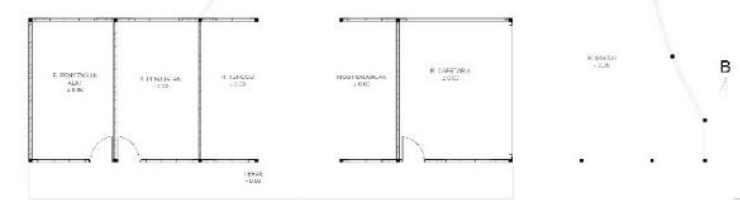

A

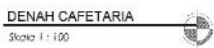

Gambar 15. Denah Kafetaria

Sumber: Penulis, 2021
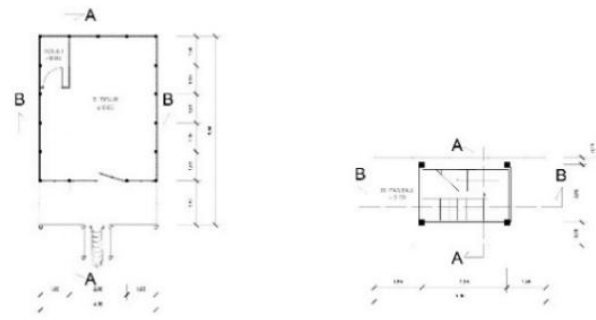

DENAH BUNGALOW

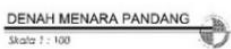

Gambar 16. Denah Bungalow dan Menara Pandang Sumber: Penulis, 2021 


\section{Tampak}

Tampak bangunan memiliki ciri khas dengan mengambil bentuk-bentuk bangunan dan material lokal. Elevasi masa bangunan dikategorikan bertingkat rendah dengan menyesuaikan tipologi bangunan tropis.

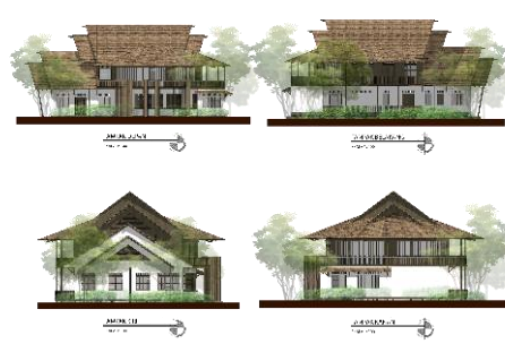

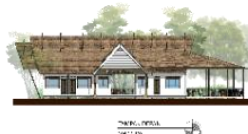
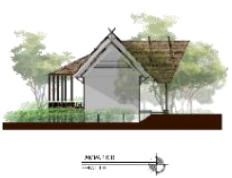
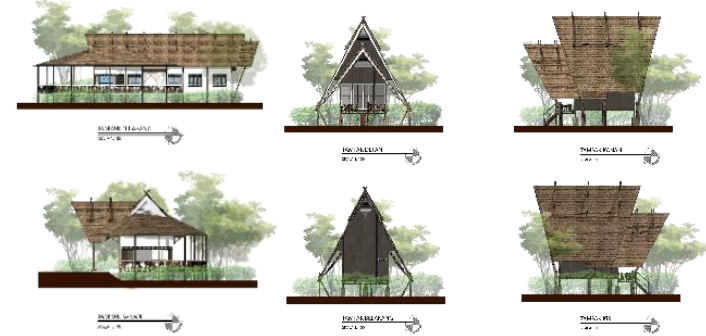

Gambar 17. Tampak Bangunan

Sumber: Penulis, 2021

\section{Potongan}

Potongan bangunan menggambarkan bagian utama bangunan berupa pengguanaan struktur serta sistem konstruksinya. Struktur dan konstruksi yang dipakai dalam perancangan. Struktur dan konstruksi yang digunakan menggunakan rangka kayu dengan kolom, balok dan plat lantai kayu serta beberapa bangunan menggunakan kombinasi beton. Konstruksi pada atap dominan menggunakan jenis atap pelana dan dikombinasikan dengan atap perisai serta struktur rangka kayu.

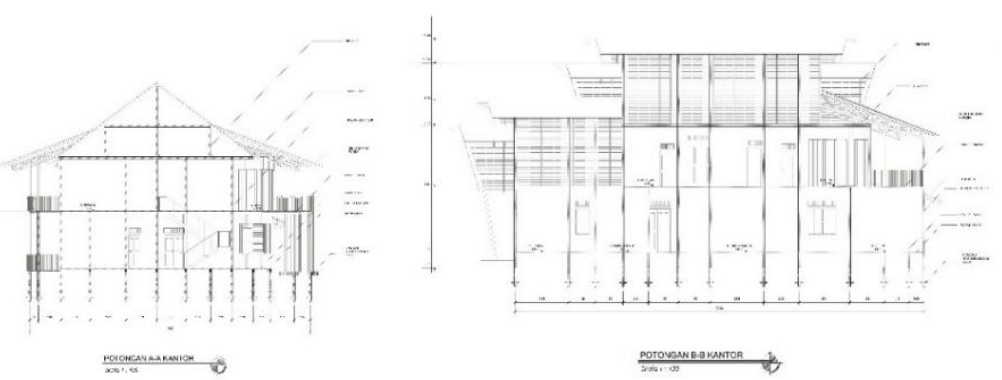

Gambar 18. Potongan Kantor Pengurus

Sumber: Penulis, 2021
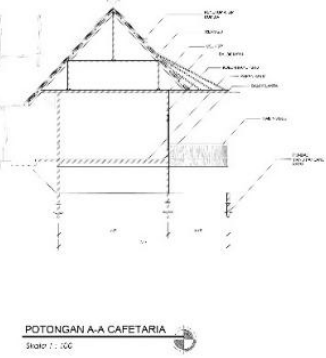
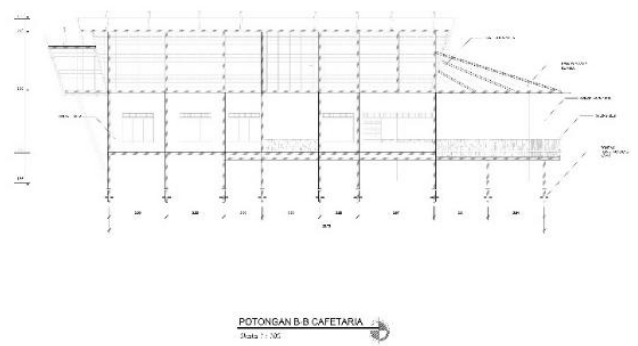

Gambar 19. Potongan Kafetaria

Sumber: Penulis, 2021 


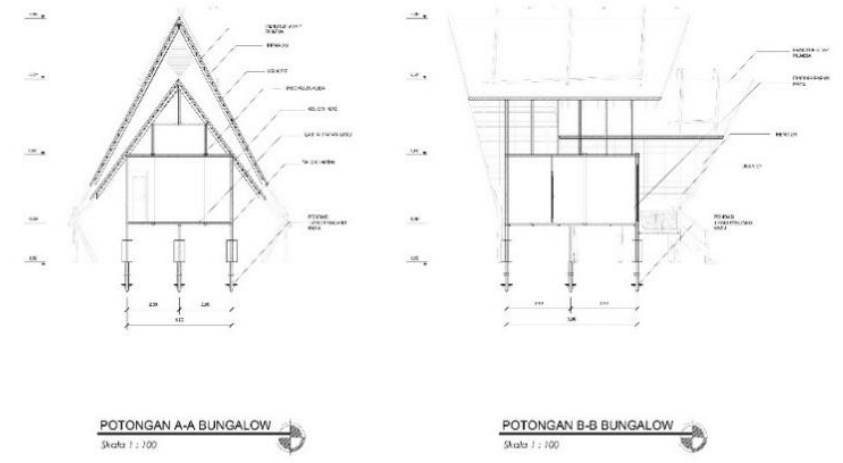

Gambar 20. Potongan Bungalow

Sumber: Penulis, 2021

\section{Suasana Ruang Luar}

Suasana ruang luar menggambarkan lingkungan kawasan wisata yang terbuka, untuk mendapatkan akses view dari bangunan ke lingkungan alami maupun sebaliknya, termasuk fasilitasfasilitas pendukung kawasan seperti plaza, parkir, jalur sirkulasi, taman, dan lain-lain. Sedangkan fungsi-fungsi khusus aktifitas rekreatif seperti area outbond, area camping, area hiking, menyesuaikan kondisi alam seperti kontur, potensi vegetasi, jalur sungai, perbukitan, air terjun, dan lain-lain.
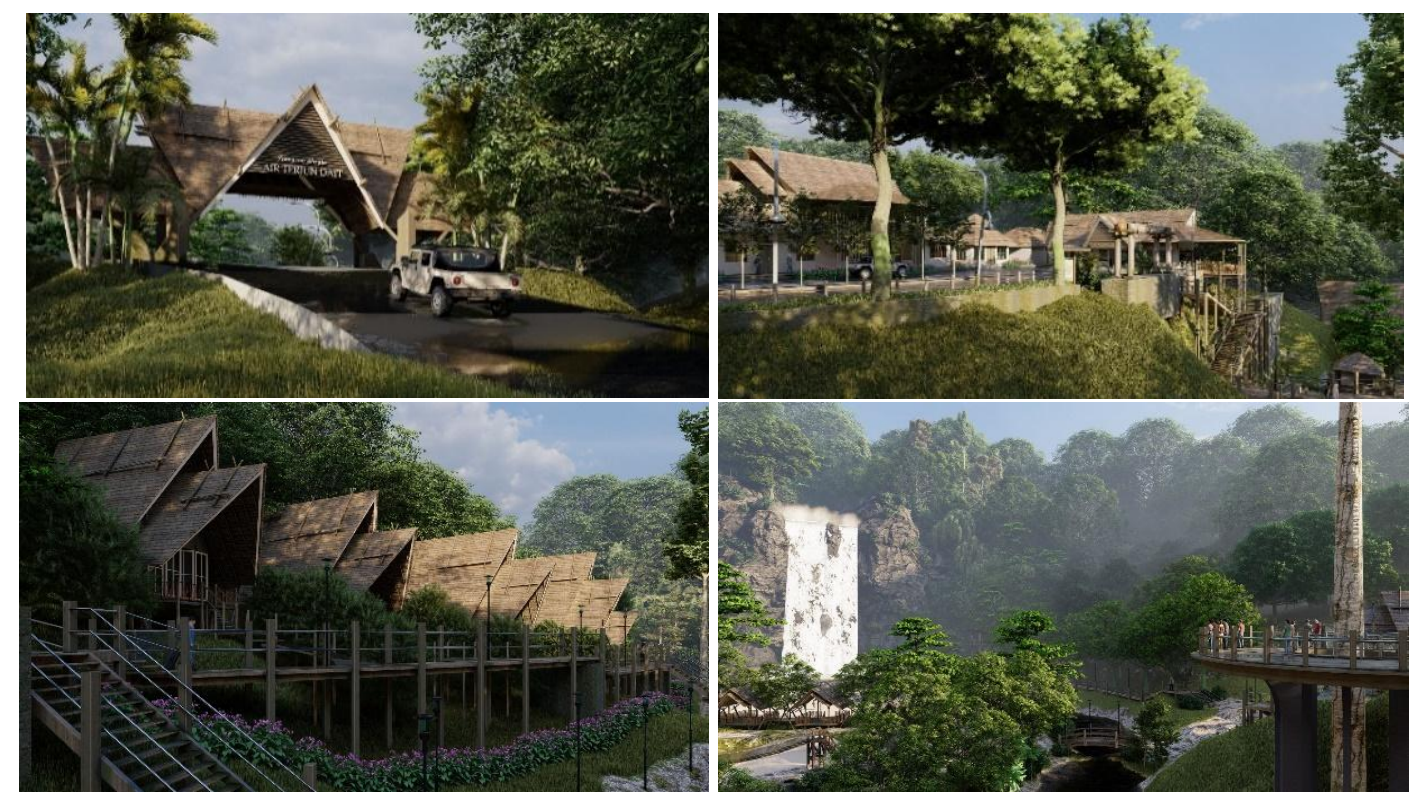

Gambar 21. Suasana Ruang Luar

Sumber: Penulis, 2021

\section{Kesimpulan}

Kesimpulan akhir perancangan memuat konsep-konsep arsitektural berdasarkan pemanfaatan potensi keindahan alam serta lingkungan berkelanjutan pada objek Air Terjun Dait. Rancangan tersebut memberikan ruang bagi masyarakat lokal untuk mengelola; menjaga, merawat, serta mengembangannya.

Diharapakan perancangan tersebut mampu mewadahi seluruh potensi kepariwisataan dan permasalahan lingkungan, menjadi lingkungan binaan yang lebih berkualitas sehingga menarik wisatawan dari dalam dan luar Kalimantan Barat. 


\section{Ucapan Terima Kasih}

Ucapan terima kasih kepada Bapak Syaiful Muazir, S.T., M.T., Ph.D., selaku Dosen Pembimbing Utama; Bapak Valentinus Pebriano, S.T., M.T., selaku Dosen Pembimbing Kedua; serta kepada seluruh Dosen dan Staf Program Studi Arsitektur Universitas Tanjungpura yang telah memberikan ilmu yang bermanfaat selama ini, kepada orang tua dan keluarga besar, serta teman-teman yang telah memberi dukungan dan bantuan dalam penggarapan tulisan ini.

\section{Daftar Acuan}

Arachchi, W. S. S. R., Yajid, A. S. M., Khatibi, A. (2015). Citation: International Journal of Business and Social Science. Eco-Touris Practices in Sri Lankan Eco Resort: An Analysis of Satisfaction and Behavioral Intention of Eco-Tourist, 6: 10

Badan Pusat Statistik Kabupaten Landak. (2007). Kabupaten Landak dalam Angka 2006/2007. Landak: BPS Kabupaten Landak

Goeldner, C. R. \& Ritchie, J. R. B. (2009). Tourism: Principles, Practices, Philosophles. $11^{\text {th }}$ ed. Wiley. Canada.

Kementerian Dalam Negeri Republik Indonesia. (2009). Peraturan Menteri Dalam Negeri Nomor 33 Tahun 2009 Tentang Pedoman Pengembangan Ekowisata di Daerah. Jakarta: Kementerian Dalam Negeri Republik Indonesia

Kementerian Kehutanan Republik Indonesia. (2012). Peraturan Menteri Kehutanan Republik Indonesia Nomor: P.22/ Menhut-II/ 2012 Tentang Pedoman Kegiatan Usaha Pemanfaatan Jasa Lingkungan Wisata Alam Pada Hutan Lindung. Jakarta: Kementerian Kehutanan Republik Indonesia

Kementerian Pariwisata, Pos, dan Telekomunikasi Republik Indonesia. (2009). SK. MENPARPOSTEL No.: KM. 98 / PW.102 / MPPT-87 Tentang Pariwisata Undang-Undang Republik Indonesia Nomor 10 Tahun 2009 Tentang Kepariwisataan. Jakarta: Kementerian Pariwisata, Pos, dan Telekomunikasi Republik Indonesia

Kementerian Pariwisata Republik Indonesia. (2018). Peraturan Menteri Pariwisata Republik Indonesia Nomor 03 Tahun 2018 Petunjuk Operasional Pengelolaan Dana Alokasi Khusus Bidang Pariwisata. Jakarta: Kementerian Pariwisata Republik Indonesia

Pemerintah Daerah Kabupaten Landak. (2010). Rencana Induk Pembangunan Kepariwisataan Kabupaten Landak. Landak: Pemerintah Daerah Kabupaten Landak

Pemerintah Daerah Kabupaten Landak. (2012). Rencana Pembangunan Jangka Menengah Daerah Kabupaten Landak 2012-2016. Landak: Pemerintah Daerah Kabupaten Landak

Pemerintah Daerah Kabupaten Landak. (2015). Rencana Tata Ruang Wilayah (RTRW) Kabupaten Landak Tahun 20142034. Landak: Pemerintah Daerah Kabupaten Landak

Sekretariat Negara Republik Indonesia. (1990). Undang-Undang No. 9 Tahun 1990 Tentang Kepariwisataan. Jakarta: Sekretariat Negara Republik Indonesia

Sekretariat Negara Republik Indonesia. (2009). Undang-Undang Republik Indonesia No. 10 Tahun 2009 Tentang Kepariwisataan. Jakarta: Sekretariat Negara Republik Indonesia

Snyder, J. C. \& Catanese, A. J. (1989). Pengantar Arsitektur. Jakarta: Erlangga

Society, The International Ecotourism. (2015). What is Ecotourism ?. Retrieved form https://ecotourism.org/what-isecotourism/

Sunaryo, B. (2013). Kebijakan Pembangunan Destinasi Pariwisata. Konsep dan Aplikasinya di Indonesia. Yogyakarta: Gava Media

Yuvensius. (2017). Citation: Jurnal Hutan Lestari. Potensi Daya Tarik Objek Wisata Air Terjun Dait di Desa Sekendal Kecamatan Air Besar Kabupaten Landak, 5(4): 1094-1099 